UDC 338.24

http://doi.org/10.21272/mmi.2018.4-05

JEL Classification: E 22

Tatsiana Tsetsiatynets,

Ph.D., Associate Professor, Belarusian State Agrarian Technical University, Belarus

Dmitry Chizh,

Ph.D., Associate Professor, Belarusian State University, Belarus

\title{
PUBLIC-PRIVATE PARTNERSHIP AS THE INNOVATIVE INSTRUMENT OF EFFECTIVE MANAGEMENT OF BELARUSIAN AGRO-INDUSTRIAL COMPLEX
}

Abstract. The purpose of the article is the scientific justification of theoretical approaches and the scientific and practical recommendations submitted on the improvement of a control system of agro-industrial complex of Belarus by means of introduction in practice of economic activity of the mechanism of public-private partnership. Limitation of the investment resources providing realization of reproduction processes in the agrarian sector of the economy of Belarus predetermines search of new sources. Effective management and development of the mechanism of publicprivate partnership will create necessary conditions for the attraction of investments into the countries of branch, priority for social and economic development, and can become an alternative to direct budgetary financing of infrastructure projects with the purpose of minimization of a subsidized component of the state budget. In article conceptual bases of formation of the mechanism of public-private partnership in the Republic of Belarus are stated. An assessment of the investment sphere of the agriculture showing a starting point of development of agro-industrial complex, in general, is given. Monitoring of a condition of fixed capital and a manpower is carried out and also the extent of their influence on a condition of the agrarian sector and the direction of his development is defined. The condition of social infrastructure in a section of such branches as education, health care and housing and communal services is studied. The scientific and practical recommendations of increase in the effective management of agroindustrial complex of Belarus in the context of the development of rural territories on the basis of the use of the mechanism of public-private partnership within the National infrastructure plan of the Republic of Belarus for 20162030 are made. An assessment of infrastructure requirements of the state for socially oriented sectors of the economy and a long-term outlook for the purpose of effective planning of the available resources and formation of the strategy of infrastructure development of the Republic of Belarus is given at the moment. The volume of the budget deficit for the financing of the available needs for infrastructure for 2016-2030 is determined. The main directions of infrastructure projects in a section of social, transport and power sectors of the economy of the Republic of Belarus are revealed and also an assessment of a possibility of their realization within the mechanism of public-private partnership is given. The new direction of implementation of projects of public-private partnership in the agro-industrial complex of Belarus with the sphere of information and communication technologies is studied. IT realization - projects will allow to improve the system of electronic payments, to upgrade the mechanism of electronic trading platforms and electronic commerce for service of this sector. Experience of state-private interaction in the developed countries in total with activization of use of tools of electronic commerce confirms prospects of development of mechanisms of public-private partnership for the solution of a number of the latest important infrastructure tasks in IT - the sector.

Keywords: public-private partnership, agro-industrial complex, management, social infrastructure, rural territories.

Introduction. Investments, being an integral part of any economic system, form the opportunities and directions of its technical, technological, socio-economic, monetary and even cultural development. They predetermine the benchmarks of innovation and scientific and technical development not only of the economy as a whole but also of its branches (types of economic activity).

World experience shows that in the modern world, not so much the volume of investment resources attracted, but how much the effectiveness of their investment, due to the list of objects, mechanisms for implementation and constant monitoring, determines the final result. In other words, at present, qualitative management of investment flows, rather than their quantitative component, is the main tool for increasing

Cite as: Tsetsiatynets, T., \& Chizh, D. (2018). Public-Private Partnership as the Innovative Instrument of Effective Management of Belarusian Agro-Industrial Complex. Marketing and Management of Innovations, 4, 54-65. http://doi.org/10.21272/mmi.2018.4-05 
the efficiency of activities of both an individual enterprise and the industry as a whole.

The economy of the Republic of Belarus has a pronounced agrarian orientation, in which the share of agriculture accounts for $7.8 \%$ of the gross domestic product, and in the agro-industrial complex as a whole almost its third. Nearly 1.5 million people are employed in the agro-industrial sector, which is about $1 / 3$ of all workers in the national economy. AIC products are one of the most important exports of the domestic economy. In recent years, food exports have increased significantly: if in 2010 it amounted to 3,387.8 million dollars (13.4\%), then in $2017-4,972.2$ million dollars (17.0\% of the total export). At the same time, the share of investments in fixed capital channelled into agriculture decreased during this period by $6.3 \mathrm{pp}$ [1]. All of the above actualizes the task of finding new sources of investment in the agrarian sector and improving the already existing tools and methods of managing them through the use of the publicprivate partnership mechanism (PPP).

Analysis of recent achievements and publications. The theoretical foundations of research in the field of managing the development of the regional economy and the problems of implementing publicprivate partnerships are based on the scientific works of foreign and domestic scientists.

The scientific rationale for the development of the regional economy through a public-private partnership is presented in the works of economists: I. S. Averina, M. E. Buyanova, V. G. Varnavskogo, A. M. Vorotnikova, M. A. Deryabinoy, A. G. Zeldner, A. A. Nikolaeva, Yu. G. Kopylova, N. V. Provalenova, Yu. V. Ragulina, and others [1-3].

Domestic economists A. M. Zaborovsky, E.P. Borushko, N. F. Ivanov, G. A. Yasheva, E. A. Daderkina, L. E. Filippova consider public-private partnerships as an organizational tool for state regulation of investment and innovation activities at the macro level [4-6].

Methodological aspects of the mechanism of public-private partnership in the agro-industrial complex of Belarus are presented in the publications of M.I. Zapolsky, S.I. Ksenzova, S.I. Kulagin and others [7]. Despite numerous studies of domestic and foreign economists on the development of relatively new forms of public-private partnership for Belarus, investment mechanisms of interaction between the state and business require further study.

The purpose of the article is to provide scientific substantiation of theoretical approaches and scientific and practical recommendations aimed at improving the management system of the agroindustrial complex through the introduction into practice of economic activity of the mechanism of publicprivate partnership.

The presentation of the main material. The need to ensure economic security and preserve national identity predetermines the state's increased attention to the process of the formation of an innovative economy. The pace of the formation of the sixth technological order is largely determined by the intensity of the renewal of the means of production, the introduction of progressive technologies and the level of development of the creative professional competences of the personnel. A special role in improving the quality of life of the population, preserving cultural traditions and strengthening the people's spirituality is played by the degree of development of rural areas and the state of the economy of the agro-industrial complex. The effectiveness of innovative transformations in agriculture is determined by the balanced legal policy of the state, the creation of innovative investment infrastructure and financial support of commodity producers, providing conditions for personal and professional development of workers in agroindustrial enterprises and residents of rural areas.

In the modern world, the main task is to manage resources, not their availability. It is this circumstance that predetermines the possibilities for the effective development of an organization, industry or national economy as a whole. The effectiveness of management of investment resources is one of the conditions for the sustainable development of the national economy, the implementation of which ensures the progressive growth and increase of the country's competitiveness in foreign markets. This task is particularly relevant for the agro-industrial complex, designed to ensure the dynamic growth of agricultural 
production, a reliable supply of the population of the country with food and consumer goods, the creation of sufficient reserves of agricultural products for export to foreign markets. In this regard, the study of investment management issues, the search for new and modernization of existing methods and mechanisms is relevant and has theoretical and practical significance [8].

The investment sphere is the locomotive of the development of any economic system. Activating and improving the efficiency of investment policy form the necessary innovation and technological reserve, which determines the possibilities for further economic development of the country. Infrastructure development is one of the key factors for maintaining long-term sustainable and balanced economic growth. The underdevelopment of this sphere gives rise to significant problems in the emergence of a business in the countryside and in improving the efficiency of functioning of agricultural and processing enterprises (Table 1).

Table 1 - Indicators of gross domestic product and investments in fixed assets in agriculture of the Republic of Belarus

\begin{tabular}{|l|c|c|c|c|c|c|c|c|}
\hline \multirow{2}{*}{ Indicators } & \multicolumn{7}{|c|}{ Years } \\
\cline { 2 - 10 } & $\mathbf{2 0 1 0}$ & $\mathbf{2 0 1 1}$ & $\mathbf{2 0 1 2}$ & $\mathbf{2 0 1 3}$ & $\mathbf{2 0 1 4}$ & $\mathbf{2 0 1 5}$ & $\mathbf{2 0 1 6}$ & $\mathbf{2 0 1 7}$ \\
\hline The share of agriculture in GDP,\% & 8,9 & 8,0 & 8,1 & 6,8 & 7,3 & 6,3 & 6,9 & 7,8 \\
\hline $\begin{array}{l}\text { Growth rate of gross value added of } \\
\text { agriculture incomparable prices as a } \\
\text { percentage of the previous year, } \%\end{array}$ & 102,3 & 107,5 & 105,8 & 96,4 & 102,5 & 97,6 & 103,8 & 105,6 \\
\hline $\begin{array}{l}\text { The share of investment in fixed } \\
\text { assets in agriculture,\% }\end{array}$ & 16,7 & 12,0 & 14,9 & 13,0 & 9,1 & 10,1 & 9,3 & 10,4 \\
\hline $\begin{array}{l}\text { The growth rate of investments in } \\
\text { fixed assets in agriculture } \\
\text { incomparable prices in a per cent to } \\
\text { the previous year,\% } \%\end{array}$ & - & 84,5 & 110,0 & 94,8 & 64,9 & 88,6 & 76,0 & 116,3 \\
\hline $\begin{array}{l}\text { The ratio of the growth rate of gross } \\
\text { value added and investment in fixed } \\
\text { assets in agriculture }\end{array}$ & - & 1,28 & 0,96 & 1,01 & 1,57 & 1,10 & 1,37 & 0,91 \\
\hline
\end{tabular}

Sources: compiled and calculated by the author on the basis of [9]; "-" - no data.

Priority of the development of the agrarian sector in Belarus is not in doubt and is confirmed by the relatively high share of agriculture in the structure of the gross domestic product, which is about $8 \%$. For the most part, the positive dynamics of the gross added value of agriculture, with the exception of the crisis years 2013-2015, was provided due to favourable economic conditions in world commodity markets and the strengthening of external demand from the main trading partners. This ensured a significant increase in exports of agricultural products and food products for the period 2010-2017. by 1584.4 million US dollars. The share of the escort of this type of product in its total volume increased from $13.4 \%$ to $17.0 \%$.

Despite the achieved positive results of the development of the agrarian sector, the state of the investment potential of the industry causes serious concerns. According to the data of Table 1 , the share of investments in fixed assets in agriculture over the study period decreased by 6.3 percentage points. The steady negative dynamics of investing in this sphere of production increases the technological gap, thereby limiting the possibilities for further innovative growth. Unfortunately, small bursts of investment activity in 2012 and 2017. They do not compensate for the technical and technological lag of the industry, thereby reducing the possibility of its progressive development based on the active introduction of innovations.

The situation in the investment sphere of agriculture in Belarus provoked significant structural changes in the technological structure of reproductive investments. For the period 2010-2017 the share of the 
active part of fixed assets in this industry has significantly decreased: the share of machinery and equipment by 3.0 percentage points, vehicles - by 0.5 percentage points The seemingly positive dynamics of livestock population growth mainly in agricultural organizations and the increase in their share in fixed assets from $4.7 \%$ in 2010 to 8.0 in 2017 is not so optimistic in reality.

The conducted studies show that the agriculture of Belarus is characterized mainly by an extensive development path, based on the involvement of additional volumes of production factors in the production turnover. For example, the development of virgin and fallow lands in the 60s. meant an extensive way of agricultural development, because New (additional) lands were put into circulation while maintaining the old material and technical base. Currently, the positive dynamics of growth in milk production is mainly due to an increase in livestock numbers, rather than the number and intensity of the introduction of modern technologies [10-13].

The important indicators characterizing the state of the investment potential of the agrarian sphere are the indicators of renewal and disposal of fixed capital. In the study period, the coefficient for the renewal of fixed assets in agricultural organizations almost halved from 12.1 to $6.9 \%$. At the same time, a positive trajectory of growth of the liquidation coefficient is noted - from 2.6 to $3.2 \%$ [9].

The revealed tendencies in aggregate testify to the growing technological backwardness of domestic agriculture and the insufficiency of attracted investment resources to eliminate the current situation. In this regard, one of the urgent tasks of increasing the efficiency of the agro-industrial complex of the republic is the search for new managerial solutions for regulating the investment and reproduction sphere.

Agriculture, being a nodal site and the core of the agro-industrial complex, accumulates in itself the investment potential of its associated branches of the processing industry, housing and utilities, transport, warehousing, and other social infrastructure. In modern conditions, the development of the agrarian sector is determined not so much by the prospects for the development of the industry, as by the directions and benchmarks of rural development. The mechanism of public-private partnership organically fits into this socio-economic system, the implementation of which allows to significantly strengthen the investment potential of the agro-industrial production based on the financing of long-term projects of investment construction of social infrastructure - education, health, housing and utilities, etc.

Despite the seemingly remote remoteness of the sectoral development of the agro-industrial complex and the implementation of infrastructure projects, their interrelationship is obvious and realizable in the context of the development of rural areas. In modern conditions, one of the main factors of production, along with the technological component, is human capital. One of the key problems in the development of the domestic agro-industrial complex is the insufficiency as well as the low level of qualification of agricultural workers. The high degree of urbanization of the population contributed to the outflow of highly qualified, young and enterprising personnel from the countryside. For the period 2010-2017 the rural population decreased by $11.8 \%$. The rate of decline of this group in working age is even more dynamic $16.3 \%$. The number of employees of organizations engaged in agriculture decreased by $20.8 \%$. One of the main reasons for activating the migration of the population to the cities, in addition to the low level of wages, is the insufficient development of the social infrastructure of rural areas.

Analyzing the state and availability of social and cultural facilities in rural areas, it should be noted that the number of rural schools is reduced due to their closure due to the low completeness, their low technical equipment, which leads to unequal conditions for obtaining a quality education. In general, there is a tendency to reduce the level of cultural services in the village. This is evidenced, for example, by the reduction of libraries, rural clubs. It is necessary to note the reduction in the number of medical stations, which indicates a decrease in the level of medical care and the provision of rural residents. It can be said that there are no cultural, health and sports facilities in the villages, so a very small percentage of rural residents, both among adults and students, are engaged in sports and physical culture. In addition, the network of trade, catering and consumer services enterprises is shrinking. Villagers are forced to spend a 
lot of time and money on trips to the city to solve their own everyday difficulties.

One of the most important areas of management of social infrastructure in rural areas is the housing policy of the state, the implementation of which is currently based on a comprehensive approach to solving problems of the sustainable functioning of the housing sector. In general, it should be noted that the indicator of housing provision of the population is growing in the country; a wide range of model projects, various forms of financial and organizational support for citizens in housing construction, as well as new approaches to building residential areas, including increasing their energy efficiency are used; expanding the range of price and planning characteristics of housing, etc.

At the same time, unresolved problems remain: provision of housing for citizens of Belarus who need better housing conditions; the presence of a regional disparity in the provision of housing to the population of large and large cities of the country, and especially the city of Minsk, and the low level of engineering and technical arrangement of housing in rural areas, small and medium-sized cities. The defining criteria for evaluating the effectiveness of the housing development policy and developing strategies for the further development of the housing sector are the sufficiency of the housing stock, which allows satisfying the population's demand for housing, housing affordability for citizens with different income levels, as well as compliance with modern quality requirements.

In terms of housing security, Belarus lags behind a number of European countries. In the republic, it is $25.4 \mathrm{~m}^{2}$ per person, while in European countries it is $30-40 \mathrm{~m}^{2}$ per person. To achieve the current average European level of provision with apartments, 423 thousand housing units need to be built in Belarus. At the current construction rate, this will take approximately 7.5 years.

The state of the social infrastructure of the territory is an indicator of the quality of life of the population and requires special attention. The main objects of rural social infrastructure include housing, medical, educational, cultural and leisure facilities, sports facilities, retail and catering facilities. The most important elements of the rural social infrastructure (after the basic one, to which housing belongs) are education and health care. The development of these components of the infrastructure creates the conditions for improving the intellectual, moral and physical health of the rural population and thus contributes to the development of the human potential of society [14].

Thus, the analysis of the relationship of the main factors of production - labour and capital, allows us to conclude about their decisive role not only on the state of the agricultural sector but on the trajectory of its further development. At the same time, the quantity and quality of social infrastructure facilities in rural areas are one of the significant factors accumulating the availability of labour and investment resources in the agro-industrial complex of Belarus. Accordingly, the efficiency of managing labour and investment flows in this sector determines the efficiency of management in the whole complex.

The social component of the competitiveness of the agricultural sector is the ability of government to create more attractive compared to other sectors of the conditions for living and recreation of the population, increasing the availability and quality of social services. The development of the social sphere in this aspect is considered an improvement in the quality of various social services to the population (education, health care, housing and communal services, etc.). Despite this, about $40-45 \%$ of the total investment is invested in transport, communications, real estate operations (including housing construction), social sphere. These data indicate priority development of infrastructure projects in the Republic of Belarus. For the period 2010 - 2017, housing construction amounted to more than 15 million $\mathrm{m}^{2}$, in healthcare organizations the number of beds increased by more than 6 thousand, the roads became longer by 2 thousand $\mathrm{km}$, in institutions of preschool and general secondary education by almost 60 thousand There are more places to learn.

The following basic mechanisms are used for the implementation of infrastructure projects in the Republic of Belarus:

1. Funding for domestic banks to provide them with available credit resources. 
2. Provision of guarantees to the Government of the Republic of Belarus for internal and external loans (loans).

3. Attraction by the Government or the Republic of Belarus of external state loans for infrastructure purposes.

4. Direct funding from the budget.

With help of the first three mechanisms, a number of projects are being implemented in the Republic to create transport and energy infrastructure facilities. The most active and efficient in the second and third mechanisms of the Republic of Belarus cooperates with the International Bank for Reconstruction and Development, the Export-Import Bank of China, the European Bank for Reconstruction and Development. The most successful examples of the implementation of infrastructure projects include the following: the use of woody biomass for district heating; development of water supply and wastewater systems; construction of roads and power lines.

The fourth mechanism (budget funds) is decisive in the development of infrastructure, including social orientation. The budgetary funds are allocated at the national and regional levels. At the republican level, the State Investment Program (SIP) is formed annually. At the regional level, each regional executive committee and the Minsk city executive committee form their investment programs. The strategic goal of the ISU is financing through public funds for the development of the material and technical base of the social sphere, which has no alternative sources of financing.

Despite the importance of infrastructure development, as well as a significant increase in demand for it, in the Republic of Belarus, there is a shortage of funds for these purposes. The bulk of investments in infrastructure accounted for by the state, which is caused by the lack of business models that generate the necessary cash flow and stimulate the participation of investors in infrastructure development. In addition, due to high capital intensity, many infrastructure facilities are not yet able to provide a level of profitability that the investor will be interested in, so the state takes on their implementation.

In addition, the possibilities for further increasing public investment in infrastructure are limited by budget constraints. During the period under review, the share of investment in fixed assets in the structure of GDP almost halved: from $33.7 \%$ in 2010 to $19.9 \%$ in 2017 . This situation is due to the tightening of monetary and fiscal policies, a reduction in lending to state programs, high inflation risks, imbalances in the external environment and a number of other reasons. As a result, the vector of investment policy has changed from reaching the maximum growth rate of investments to increase the efficiency of their management.

In modern economic conditions, in order to successfully implement large infrastructure projects of national importance, it is necessary to combine efforts and interests on the part of state authorities and representatives of private business in order to achieve the maximum effect in the framework of this cooperation. The public-private partnership is at the present stage of development of the Belarusian economy the most universal and effective mechanism for the interaction of this cooperation.

The importance of the institution of public-private partnership in Belarus is increasing every year, creating the necessary effect for the development of the agrarian sector. An analysis of the practice of applying the public-private partnership mechanism at various levels indicates that this system is one of the best options for managing investment resources. With a well-formed structure of the PPP mechanism, as well as the optimal choice of forms, its use is extremely beneficial both for the state and for representatives of the private sector, and especially for the population [5].

A large-scale experience in the redistribution of property rights between the state and private business is observed, first of all, in the so-called sectors of public services (in particular, in the infrastructure sectors). It is in these industries that the traditions of the delegation of a number of key competencies to the private sector have historically been formed. In the United States, according to the National Council on PublicPrivate Partnerships, commercial firms are used in the execution of 23 of the 65 basic activities of local 
authorities (plumbing, sewage, garbage collection, school education, etc.) [6].

The main objectives of creating PPPs are to allocate the necessary resources for infrastructure, increase the efficiency of service provision, improve management at state enterprises through the introduction of the principles of functioning of private firms and the opening of this sector to market competition. In recent years, the share of PPPs in the total public infrastructure investment amounts to $15-25 \%$ in the UK [15].

According to McKinsey Global Institute estimates, to maintain an adequate state of infrastructure, the total value of infrastructure assets should average $70 \%$ of gross domestic product. Those countries whose share is lower should increase their investment in infrastructure at a faster pace. By investing in infrastructure, new jobs are created, the production and transport costs of enterprises are reduced, and the social sphere is developed. The cumulative result of infrastructure investments is sustainable economic growth and improvement in the quality of life of the population.

The implementation of the PPP mechanism in the framework of the National Infrastructure Plan of the Republic of Belarus for 2016-2030 (NIP) has a significant impact on the development of the agro-industrial sector. This is a pilot version of the assessment of the country's existing infrastructure needs for the long term and improving the methodology for strategic planning of infrastructure development. The NIP is one of the orientation documents for the business community, which is aimed at attracting it to finance the construction of new and reconstruction of existing infrastructure on the principles of PPP [16].

Taking into account the continuity of the promising areas of economic development of the Republic of Belarus and the role of the most important factors in achieving socio-economic goals, the development of the NIP focuses on the following priority areas identified by the National Strategy for Sustainable SocioEconomic Development until 2030 for the coming decade:

- human development through the provision of high-quality services within the framework of social infrastructure;

- achieving economic growth due to the high quality of industrial infrastructure facilities;

- improving the environmental safety of infrastructure facilities;

- development of entrepreneurship and initiatives through the use of new forms of agreements on the principles of public-private partnership;

- introduction of innovative solutions and new technologies in the creation, management and maintenance of infrastructure facilities.

The development of a NIP will facilitate:

- analysis of the state of the infrastructure of the Republic of Belarus, including the latest data on its performance;

- the formation of a common vision of the existing infrastructure needs of the state in various sectors of the economy for the current and long-term perspective in order to effectively plan the available resources and formulate a strategy for the infrastructure development of the Republic of Belarus;

- implementation of infrastructure projects taking into account their priority;

- determine the amount of the budget deficit to finance the existing infrastructure needs and the necessary actions of the state to overcome it;

- implementation of measures to improve the state of the environment through the introduction of new technologies and infrastructure development;

- development of PPP in the Republic of Belarus.

In addition, the NIP will serve as a marketing tool for the state when dealing with the public and private business. Through this document, representatives of the business community who are interested in cooperation with the state in implementing infrastructure projects will receive the most complete and reliable information about the long-term plans and strategy of the Government of the Republic of Belarus regarding the construction and reconstruction of infrastructure facilities. This will increase the effectiveness 
of the management decisions taken to finance and implement long-term infrastructure projects, including in the agro-industrial complex of Belarus.

The implementation of the national infrastructure plan will allow:

1. Solve the problem of providing and developing infrastructure in conditions of limited budgetary funds.

2. To increase the level of infrastructure development in the regions of the Republic of Belarus, on which the effectiveness of development of a specific territory directly depends.

3. Ensure the provision of higher quality infrastructure services to citizens of the Republic of Belarus.

Within the framework of the NIP of the Republic of Belarus, the development of infrastructure for 2016 2030 in its main areas is predicted: energy; transport; social infrastructure (excluding housing and communal services); housing infrastructure; other infrastructure.

In the long term to 2020 , the need for funds for the creation of infrastructure facilities is estimated at \$ 18.1 billion, and the next decade $-\$ 62.3$ billion. In the medium term, priority investment projects will be housing and utility facilities and the transport industry. It is assumed that the share of investments in fixed assets for the development of these industries will be 43.4 and $31 \%$, respectively. In the long term, the main vector of investment policy will not change significantly. The total share of investments aimed at financing the housing and transport sectors of the economy will be $78.6 \%$. The capital intensity of the social sphere also remains almost unchanged: 15.9-15.5\%. Effective modernization of the energy industry will reduce investment costs in the long term almost by half: from 9.7 to $5.9 \%$ by 2030 (Table 2).

Table 2 - Assessment of the need for investment in the main areas of infrastructure in the medium and long-term

\begin{tabular}{|l|c|c|c|c|}
\hline \multirow{2}{*}{ Infrastructure Directions } & \multicolumn{2}{|c|}{ until 2020 } & \multicolumn{2}{c|}{ 2021-2030 years } \\
\cline { 2 - 5 } & Million USD & \% & Million USD & \% \\
\hline Total, including & 18060,3 & 100 & 44458,3 & 100 \\
\hline Social & 2870,3 & 15,9 & 6885,2 & 15,5 \\
\hline Transport & 5600,0 & 31,0 & 17441,0 & 39,2 \\
\hline Energetic & 1757,9 & 9,7 & 2609,2 & 5,9 \\
\hline Housing and communal services & 7832,1 & 43,4 & 17522,9 & 39,4 \\
\hline
\end{tabular}

Sources: [16].

Based on the available and forecast data of local and regional budgets and state investment programs for the period from 2016 to 2030. An assessment of the needs of the Republic of Belarus for infrastructure investments was carried out (Figure 1).

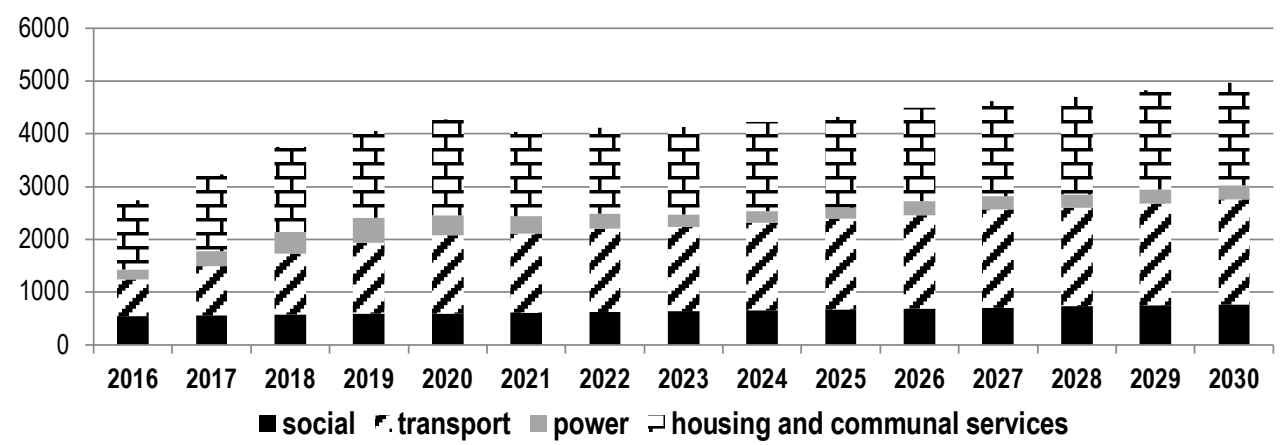

Figure 1 - The need for investment in infrastructure by industry for 2016 - 2030, million USD. Sources: compiled by the authors on the basis of [16]. 
Based on the presented forecast of the needs of the Republic of Belarus in 2016-2030. The calculation of the infrastructure gap (funding gap), which represents the difference between the needs and the actual costs of infrastructure projects. The minimum value of the gap is at the level of 713.4 million US dollars, the maximum value is 2263.3 million US dollars. The average annual forecast deficit for the period 2016 -2030 . amounts to $\$ 1.83$ billion, i.e. it is projected to increase by almost 4 times over the next 15 years (Figure 1).

The planned average annual volume of costs for the period 2016-2020. will be 2 billion dollars with a projected increase to 2.7 billion dollars by 2027. At the same time, the average annual need of the Republic of Belarus in infrastructure investments for the period 2016-2020. will amount to $\$ 3.58$ billion. Thus, the average annual budget deficit for the development of the infrastructure of the Republic of Belarus in the period from 2017 to 2020 will amount to $\$ 1.5$ billion (Figure 2).

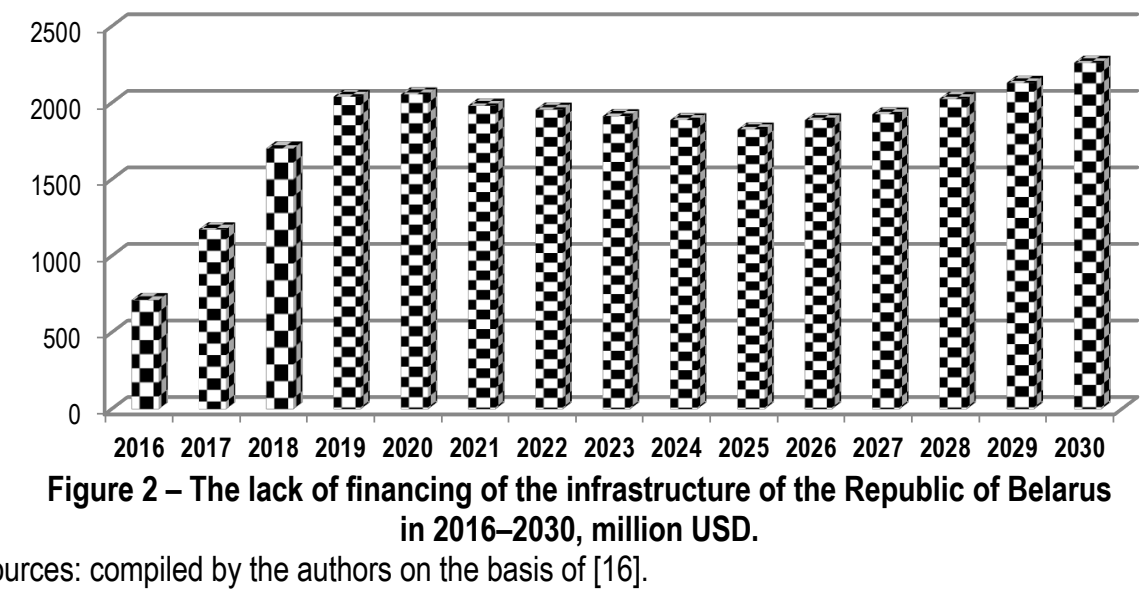

Based on the general need of the country for infrastructure facilities, in coordination with the governing bodies of the Interdepartmental Infrastructure Coordination Council, the main directions for the development of infrastructure projects in the context of industries that meet the priorities of the socioeconomic development of the Republic of Belarus were identified. The main sources of financing for the implementation of these areas are funds raised under PPP agreements, investment contracts, borrowed funds, as well as other sources not prohibited by the legislation of the Republic of Belarus.

The main directions of development of social infrastructure are:

1. In the field of education: reconstruction and construction of kindergartens, schools, child development centres, educational and pedagogical complexes.

2. In the field of public health: reconstruction and construction of hospitals, polyclinics, outpatient and diagnostic centres.

3. In the field of culture: construction and reconstruction of palaces of culture, cultural and entertainment complexes, museum complexes, as well as the reconstruction of objects of historical and cultural heritage.

4. In the field of sports and tourism: the construction and reconstruction of physical education and sports and recreation complexes, indoor tennis courts, swimming pools, stadiums.

Taking into account the geographical position of the Republic of Belarus, located at the junction of the two economic spaces of the European Union and Eurasia, considerable attention is paid to the modernization of roads, railways and airports in order to strengthen the transport potential in the country. 
The main priority of the development of the energy sector is to meet the needs of the economy of the republic and the population in electric and thermal energy, increase reliability, economic and technological efficiency of the energy system, taking into account the commissioning of the Belarusian NPP.

Achievement of this goal is expected to be implemented on the basis of balanced development and modernization of generating sources, electric and thermal networks of the energy system based on the introduction of innovative technologies and the decommissioning of physically and morally obsolete power equipment, reducing the cost of production and transportation of electricity and heat. The development of housing and communal services in the medium term includes:

- commissioning of 14.6 million square meters of residential buildings after major repairs, which will allow to bring the proportion of the capital repairs to $3 \%$ of the serviced area and to provide repair once every $30-35$ years;

- improving the quality of services through the timely prevention of intensive wear, restoration of serviceability and elimination of damage to structural elements, engineering systems;

- replacement of 3.2 thousand $\mathrm{km}$ of heating networks, which will reduce the loss of heat energy in the networks by up to $10 \%$;

- the introduction of energy-saving measures, the implementation of which will allow saving at least 625 thousand tonnes of fuel equivalent for fuel and energy resources;

- improving the quality of services and reducing water losses through the timely repair of networks, as well as other water supply and sanitation facilities.

In addition, as part of the implementation of the National Infrastructure Plan, it is expected to increase the volume of secondary material resources involved in circulation - paper and cardboard waste, glass waste, polymer waste, used tires, household appliances waste, used batteries, used engine oils - 1.5 times compared with 2015 and achieving a level of extraction of secondary material resources from municipal waste of at least $25 \%$ in 2020.

At the same time, the interaction of public and private partners in the information technology industry is not clearly spelt out [17]. However, the need to attract private companies to solve important socioeconomic problems is not limited only to the production sphere. The realities of the modern world dictate the need for the widespread informatization of all spheres of life, including the creation of powerful and efficient information systems and the digitization of technical services.

An analysis of current practices and regulatory legal acts of Western countries indicates a gradual expansion of the IT industry sector in the field of public-private partnership. Thus, in the UK and France, such contracts account for between $5 \%$ and $10 \%$ of PPPs, and in Germany, where the legal basis for the interaction of the public and private sectors in the information sphere was created in 1999, this sector became one of the main and most successful. The participants of the international conference "The Role of PPP Projects in Achieving the Sustainable Development Goals and Improving People's Wealth", held on September 12, 2018, in Minsk, from Ukraine, the Russian Federation, Kazakhstan, Germany and other countries of the European Union agreed on this point.

In this regard, in addition to the above areas of implementation of infrastructure projects, a promising guide for the development of the Institute of public-private partnership in Belarus in general, and the agroindustrial complex, in particular, is joint financing of projects in the field of information and communication technologies (ICT). The objects of such agreements may be computer programs, databases, information systems and websites on the Internet or other networks, or technologically related IT objects and property. In order to successfully implement IT projects, intangible assets can be supplemented with fixed assets that are technologically related to IT facilities and intended for automation. This will make it possible to more effectively attract private capital to solve state tasks in the field of ICT, in particular, to create importsubstituting developments, which is especially important in the context of the digital economy development. 
The implementation of IT projects in the agro-industrial complex of Belarus will make it possible to improve the system of electronic payments, modernize the mechanism of electronic trading platforms and e-commerce to serve this sector. The experience of public-private interaction in developed countries in conjunction with the increased use of e-commerce tools confirms the prospects for the development of PPP mechanisms for solving a number of the latest important infrastructure tasks in the IT sector.

Summing up, it should be noted that the use of the public-private mechanism is currently an alternative and effective way to improve the management of the investment sphere, as well as a promising benchmark for rural development. Strengthening the innovation and reproduction potential of the latter will determine the points of growth of agriculture and associated industries and infrastructure, thereby ensuring investment priorities of the innovative development of the agricultural sector of Belarus.

\section{References}

1. Byaynova M. E., Averina I. S. \& Kopilova Y. G. (2017). Assessment of experience of realization by regions of Russia ecological projects on the basis of public-private partnership. Regional economy. South of Russia, № 3 (17), 140-150.

2. Varnavskiy, V.G. (2015). Private and public partnership in the industry of Russia. Bulletin of institute of economy of the Russian Academy of Science, №5, 41-54.

3. Provalenova. N. V., \& Nikolaeva A. A. (2014). Ordering of approaches to definition of state-private partnership. World of science, №4, 3-14.

4. Barushka, E. P. \& Ivanoy, V. F.(2016). Use of mechanisms of public-private partnership in the innovative sphere of Republic of Belarus. Bank bulletin, №7, 32-38.

5. Yermolovich, M. L. \& Daderkina, E. A. (2014) Long-term planning of development of infrastructure: foreign experience and formation of the national infrastructure plan in Republic of Belarus. Finance, account, audit, № 11, 6-15.

6. Zaborovsky, A. M., Yermolovich, L. \& Daderkina E. A. (2014). Public-private partnership: the international experience and prospects for Belarus. Finance, account, audit. № 9, 23 - 37.

7. Zapolsky. M. I. (2016). Methodology for formation of state-private partnership in the agriculture of Belarus. Proceedings of the National Academy of Sciences of Belarus. Series of Agrarian Sciences, № 2, 67-79.

8. Ryzhenkova, N. E. \& Chepik D. A. (2014). Development of innovative capacity of agrarian and industrial complex: problems, directions. Rural economics of Russia, №6, $53-57$.

9. Agriculture of Republic of Belarus: statistical collection (2018). Minsk: National statistical committee, 235.

10. Shimko, D. S., Kubrak, M. S. \& Volodko, O. V. (2016). State and the prospects of development of agro-industrial complex in Republic of Belarus. Aekonomika: economy and agriculture, №4 (12), 14-17.

11. Gusakov, V. G. (2015) Mechanisms of the sustainable balanced development of grocery structures within cluster institutional space of food system of the Eurasian Economic Union. Proceedings of the National Academy of Sciences of Belarus. Series of Agrarian Sciences, № 2, 4-18.

12. Shpak A. P. (2016) The development strategy of agrarian and industrial complex of Belarus in the conditions of the Euroasian integration. Proceedings of the National Academy of Sciences of Belarus. Series of Agrarian Sciences, №. 4, 13-20.

13. Tsetsiarynets T. A., Sinelnihay, V. M., Chizh D. A. \& Popov A. I. (2018). Productive and economic potential of agriculture of Belarus: analysis and mechanisms of management: monograph. Tambov, 160.

14. Bishop, K., Heim B. T., \& Mihaly K. (2009). Single Women's Labor Supply Elasticities : Trends and Policy Implications // Industrial and Labor Relations Review, V.63, №1, 146 - 168.

15. Martusevich, R. A. (2016). Public-private partnership in municipal services. Fund «Institute of City Economy», 154 p.

16. National infrastructure plan 2016 - 2030. Ministry of Economics of Republic of Belarus [an electronic resource]. http://www.economy.gov.by/dadvfiles/002833_728128_3.pdf. Date of access 9.18.2018.

17. The law of Republic of Belarus of December 30 (2015). «About public-private partnership», №. 345-L.

T. Тетеринец, Ph.D., доцент, Білоруський державний аграрний технічний університет (Республіка Білорусь);

Д. Чиж, Ph.D., доцент, Білоруський державний університет (Республіка Білорусь).

Публічно-приватне партнерство як інноваційний інструмент ефективного управління агропромисловим комплексом Республіки Білорусь

Метою статті $\epsilon$ наукове обгрунтування теоретичних підходів та науково-практичних рекомендацій щодо підвищення ефективності системи управління агропромисловим комплексом Республіки Білорусь шляхом впровадження в практику 
T. Tsetsiatynets, D. Chizh. Public-Private Partnership as the Innovative Instrument of Effective Management of Belarusian Agro-Industrial Complex

господарської діяльності механізму публічно-приватного партнерства. Обмеження та нестача інвестиційних ресурсів, що забезпечують реалізацію процесів відтворення в аграрному секторі Республіки Білорусь, зумовлюють необхідність пошуку та впровадження нових інвестиційних джерел. Ефективне управління та розвиток механізму публічно-приватного партнерства створює необхідні умови для залучення інвестицій у галузі, які $є$ пріоритетними для забезпечення соціальноекономічного розвитку країни та може стати альтернативним напрямом бюджетного фінансування інфраструктурних проектів з метою мінімізації субсидованої частини державного бюджету. у статті викладено концептуальні основи формування механізму публічно-приватного партнерства в Республіки Білорусь. Авторами здійснено оцінку інвестиційної привабливості сільського господарства з точки зору ключової детермінанти розвитку агропромислового комплексу в цілому. У статті проведено аналіз ефективності використання основного капіталу та трудових ресурсів, а також ступінь ї впливу на функціонування та розвиток аграрного сектору. Авторами досліджено стан соціальної інфраструктури в таких секторах як: освіта, охорона здоров'я та житлово-комунальне господарство. На основі результатів дослідження було розроблено науково-практичні рекомендації щодо підвищення ефективності управління агропромисловим комплексом Республіки Білорусь в контексті розвитку сільських територій на основі використання механізму публічно-приватного партнерства в рамках Національного інфраструктурного плану Республіки Білорусь на 2016-2030 рр. У статті здійснено оцінку інфраструктурних вимог держави до соціально орієнтованих галузей економіки та здійснено довгостроковий прогноз з метою ефективного планування наявних ресурсів та формування стратегії розвитку інфраструктури Республіки Білорусь. Визначено обсяг дефіциту бюджету для фінансування наявних потреб на розвиток інфраструктури на 2016-2030 роки. Виявлено основні напрямки інфраструктурних проектів у соціальному, транспортному та енергетичному секторах економіки Республіки Білорусь, а також оцінено можливості ї реалізації в рамках механізму публічно-приватного партнерства. Автори досліджують новий напрямок реалізації проектів публічно-приватного партнерства в агропромисловому комплексі Республіки Білорусь із залученням інформаційно-комунікаційних технологій. Дані технології дають можливість підвищити ефективність системи електронних платежів, оновити механізм електронних торговельних платформ та електронноі комерції для обслуговування агропромислового сектору. Результати дослідження зарубіжного досвіду взаємодії державаприватний сектор з активізацією використання IT технологій підтверджує перспективи розвитку механізмів публічноприватного партнерства для вирішення низки нагальних інфраструктурних завдань у всіх галузях економіки.

Ключові слова: публічно-приватне партнерство, агропромисловий комплекс, управління, соціальна інфраструктура, сільські території.

Manuscript received: 24.09.2018

(C) The author(s) 2018. This article is published with open access at Sumy State University. 